
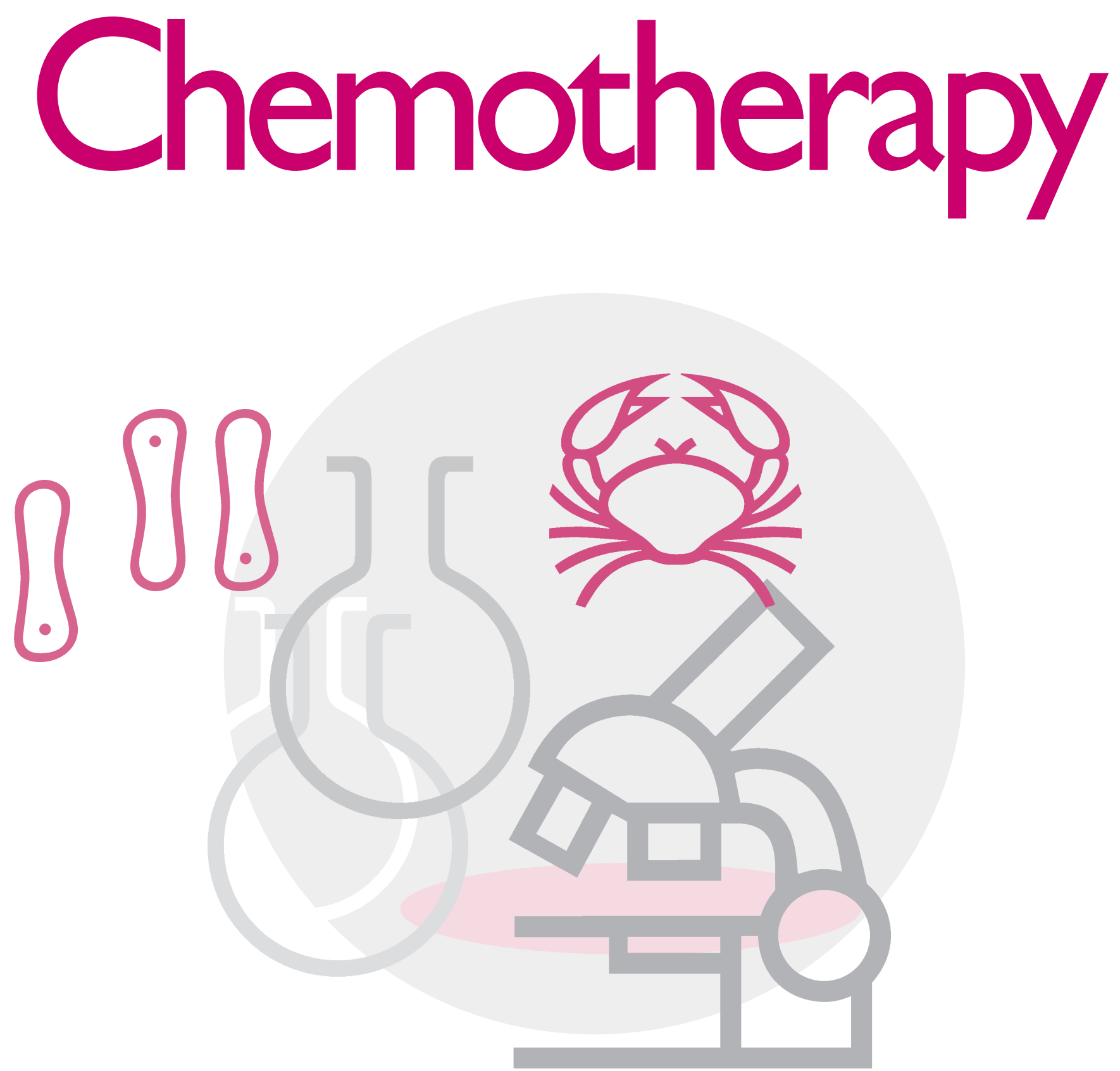


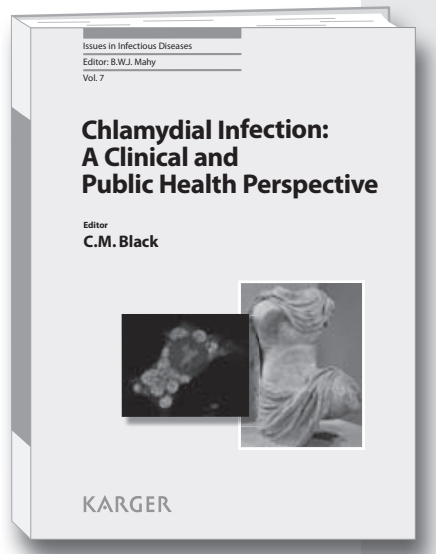

Chlamydial Infection: A Clinical and Public Health Perspective

Editor: Black, C.M. (Atlanta, Ga.)

$\mathrm{VI}+162$ p., 12 fig., 3 in color, 12 tab., 2013

CHF 117.- / EUR 98.- / USD 138.00 (hard cover)

CHF 140.- / EUR 118.- / USD 166.00 (online)

Online version for institutional purchase

Prices subject to change

EUR price for Germany, USD price for USA only

ISBN 978-3-318-02398-5 (hard cover)

e-ISBN 978-3-318-02399-2

Issues in Infectious Diseases, Vol. 7

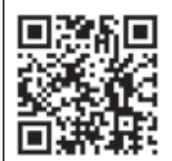

Dear Librarian

I have reviewed this publication and

would like to recommend it for our library.

Recommended by:

Department:

Date:

Signature:

Orders may be placed with any bookshop

\section{Chlamydial Infection: A Clinical and Public Health Perspective}

\author{
Editor \\ Carolyn M. Black
}

Chlamydiae are obligate intracellular bacteria that cause one of the most common sexually transmitted infectious diseases in the world. The infection disproportionately impacts women and the highest prevalence of infection is found in adolescents. Most chlamydial infections are asymptomatic. Untreated infections are sources of further spread of infection and can lead to serious consequences including pelvic inflammatory disease, infertility and chronic pelvic pain. Chlamydial infections also increase a person's susceptibility to HIV and other STDs.

Featuring contributions by internationally recognized experts in epidemiology, infectious disease research and chlamydial biology, this book provides up-to-date reviews from a clinical and public health perspective on chlamydia epidemiology and control programs, genomics and pathogenicity, diagnosis, treatment, host immune responses, and the latest on the search for an effective vaccine. Also included are chapters on the impact of chlamydial infection on specific populations such as the lesbian, gay, bisexual and transgender community, and an update on the outbreak in Europe of the invasive chlamydial infection, lymphogranuloma venereum or LGV. This comprehensive publication is intended for clinicians, public health workers and scientists with interest in sexually transmitted diseases, medical microbiology, infectious diseases and clinical research.

\section{Contents}

Introduction: Black, C.M.

- Epidemiology and Prevention and Control Programs for Chlamydia: Satterwhite, C.L.; Douglas Jr., J.M.

- Chlamydia trachomatis Pathogenicity and Disease: Dean, D.

- Chlamydia trachomatis Genome Structure Putman, T.E.; Rockey, D.D.

- Chlamydia trachomatis: Molecular Testing Methods: Gaydos, C.A.

- Treatment of Chlamydia trachomatis Infections: Hammerschlag, M.R.

- The Immunologic Response to Urogenital Infection: Johnson, R.M.; Geisler, w.

-Chlamydia Vaccine Development: Igietseme, J.U.; Black, C.M.

- Maternal and Infant Chlamydia trachomatis Infections: Rours, I.G.I.J.G.; Hammerschlag, M.R. - Chlamydia trachomatis Infection among Sexual Minorities: Singh, D.; Marrazzo, J.M.

- Lymphogranuloma Venereum: A Concise Outline of an Emerging Infection among Men Who Have Sex with Men: de Vries, H.J.C.; Morré, $\mathbf{S}$.

- Author Index

- Subject Index 


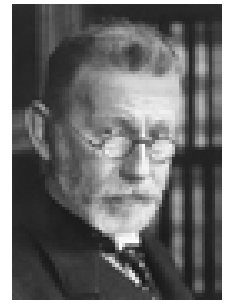

Paul Ehrlich 1854-1915

The founder of chemotherapy

\section{Editor-in-Chief}

F. Sörgel, Nürnberg-Heroldsberg

\section{Chemotherapy}

International Journal of Experimental and Clinical Chemotherapy

Founded 1959 as 'Chemotherapia' by H.P. Kuemmerle and P. Rentchnick Continued by H. Schönfeld (1968-2001)

\section{Editorial Board}

C. Chiesa, Rome

S. Horkovics-Kovats, Kundl

S. Kohno, Nagasaki

C. Landersdorfer, Melbourne, Vic.

R.C. Moellering Jr., Boston, Mass.

K.G. Naber, Straubing
R. Nau, Göttingen

D. Nix, Tucson, Ariz.

P. Preziosi, Rome

J.C. Stingl, Bonn

M. Wilhelm, Nürnberg

F. Van Bambeke, Brussels 


\section{Chemotherapy}

\section{Submission}

Only original papers written in English are considered for publication. Manuscripts should be submitted to Chemotherapy online. For specific instructions on how to prepare a manuscript for submission, you are encouraged to view the guidelines at www.karger.com/ che, where you will also find a link to the Submission Website. Names, postal and e-mail addresses of four experts in the appropriate area of research should accompany each manuscript. Selected scientist(s) will be invited to act as referee(s). Referees suggested should not be from the same institution as the author and should have expert knowledge of the subject. Should you have any problems with your submission, please contact:

Prof. F. Sörgel

S. Karger AG

Editorial Office 'Chemotherapy'

P.O. Box

CH-4009 Basel (Switzerland)

Tel. $\quad+41613061361$

Fax $\quad+41613061434$

E-Mail che@karger.com

Mailing address for courier deliveries only:

Allschwilerstr. 10

CH-4055 Basel (Switzerland)

\section{Conditions}

All manuscripts are subject to editorial review. Manuscripts are received with the explicit understanding that they are not under simultaneous consideration by any other publication. Submission of an article for publication implies the transfer of the copyright from the author to the publisher upon acceptance. Accepted papers become the permanent property of Chemotherapy and may not be reproduced by any means, in whole or in part, without the written consent of the publisher. It is the author's responsibility to obtain permission to reproduce illustrations, tables, etc. from other publications.

\section{Arrangement \\ Lines should be numbered on the margin.}

Title page: The first page of each paper should indicate the title, the authors' names, the institute where the work was conducted, and a short title for use as running head.

Full address: The exact postal address of the corresponding author complete with postal code must be given at the bottom of the title page. Please also supply phone and fax numbers, as well as e-mail address.

Key words: Please supply 3-10 key words in English that reflect the content of the paper.

Abstract: Each paper needs an abstract of up to 150 words structured with subheadings as follows: Background, Methods, Results, Conclusion(s).

Footnotes: Avoid footnotes. When essential, they are numbered consecutively and typed at the foot of the appropriate page.

Tables and illustrations: Tables and illustrations (both numbered in Arabic numerals) should be prepared on

Photo on title page

Courtesy of the Paul-Ehrlich-Institut, Langen, Germany separate sheets. Tables require a heading and figures a legend, also prepared on a separate sheet. For the reproduction of illustrations, only good drawings and original photographs can be accepted; negatives or photocopies cannot be used. Due to technical reasons, figures with a screen background should not be submitted. When possible, group several illustrations on one block for reproduction (max. size $180 \times 223 \mathrm{~mm}$ ) or provide crop marks. Electronically submitted b/w half-tone and color illustrations must have a final resolution of $300 \mathrm{dpi}$ after scaling, line drawings one of 800-1,200 dpi.

Color illustrations

Online edition: Color illustrations are reproduced free of charge. In the print version, the illustrations are reproduced in black and white. Please avoid referring to the colors in the text and figure legends.

Print edition: Up to 6 color illustrations per page can be integrated within the text at CHF 800 .- per page.

References: In the text identify references by Arabic numerals [in square brackets]. Material submitted for publication but not yet accepted should be noted as 'unpublished data' and not be included in the reference list. The list of references should include only those publications which are cited in the text. Do not alphabetize; number references in the order in which they are first mentioned in the text. The surnames of the authors followed by initials should be given. There should be no punctuation other than a comma to separate the authors. Preferably, please cite all authors. Abbreviate journal names according to the Index Medicus system. Also see International Committee of Medical Journal Editors: Uniform requirements for manuscripts submitted to biomedical journals (www.icmje.org).

\section{Examples}

(a) Papers published in periodicals: Sun J, Koto $\mathrm{H}$ Chung KF: Interaction of ozone and allergen challenges on bronchial responsiveness and inflammation in sensitised guinea pigs. Int Arch Allergy Immunol 1997;112:191-195.

(b) Papers published only with DOI numbers:

Theoharides TC, Boucher W, Spear K: Serum interleukin-6 reflects disease severity and osteoporosis in mastocytosis patients. Int Arch Allergy Immunol DOI: $10.1159 / 000063858$

(c) Monographs: Matthews DE, Farewell VT: Using and Understanding Medical Statistics, ed 3, revised. Basel, Karger, 1996

(d) Edited books: Parren PWHI, Burton DR: Antibodies against HIV-1 from phage display libraries: Mapping of an immune response and progress towards antiviral immunotherapy; in Capra JD (ed): Antibody Engineering. Chem Immunol. Basel, Karger, 1997, vol 65, pp 18-56.

Reference Management Software: Use of EndNote is recommended for easy management and formatting of citations and reference lists.

\section{Digital Object Identifier (DOI)}

S. Karger Publishers supports DOIs as unique identifiers for articles. A DOI number will be printed on the title page of each article. DOIs can be useful in the future for identifying and citing articles published online without volume or issue information. More information can be found at www.doi.org.

\section{Supplementary Materia}

Supplementary material is restricted to additional data that are not necessary for the scientific integrity and conclusions of the paper. Please note that all supplementary files will undergo editorial review and should be submitted together with the original manuscript. The Editors reserve the right to limit the scope and length of the supplementary material. Supplementary material must meet production quality standards for Web publication without the need for any modification or editing. In general, supplementary files should not exceed $10 \mathrm{Mb}$ in size. All figures and tables should have titles and legends and all files should be supplied separately and named clearly. Acceptable files and formats are: Word or PDF files, Excel spreadsheets (only if the data cannot be converted properly to a PDF file), and video files (.mov, .avi, .mpeg).

\section{Author's Choice ${ }^{\mathrm{TM}}$}

Karger's Author's Choice ${ }^{\mathrm{TM}}$ service broadens the reach of your article and gives all users worldwide free and full access for reading, downloading and printing at www.karger.com. The option is available for a onetime fee of CHF 3,000.-, which is a permissible cost in grant allocation. More information can be found at www.karger.com/authors_choice.

\section{NIH-Funded Research}

The U.S. National Institutes of Health (NIH) mandates under the NIH Public Access Policy that final, peer-reviewed manuscripts appear in its digital database within 12 months of the official publication date. As a service to authors, Karger submits the final version of your article on your behalf to PubMed Central. For those selecting our premium Author's Choice ${ }^{\mathrm{TM}}$ service, we will send your article immediately upon publishing, accelerating the accessibility of your work without the usual embargo. More details on NIH's Public Access Policy is available at http://publicaccess.nih.gov/FAQ.htm\#al

\section{Self-Archiving}

Karger permits authors to archive their pre-prints (i.e. pre-refereeing) or post-prints (i.e. final draft post-refereeing) on their personal or institution's servers, provided the following conditions are met: Articles may not be used for commercial purposes, must be linked to the publisher's version, and must acknowledge the publisher's copyright. Authors selecting Karger's Author's Choice ${ }^{\mathrm{TM}}$ feature, however, are also permitted to archive the final, published version of their article, which includes copyediting and design improvements as well as citation links.

\section{Page Charges}

There is no page charge for papers of 3 or fewer print ed pages (including tables, illustrations and references). Each additional complete or partial page is charged to the author at CHF 325.-. The allotted size of a paper is equal to approx. 9 manuscript pages (including tables, illustrations and references).

\section{Proofs}

Unless indicated otherwise, proofs are sent to the corresponding author and should be returned with the least possible delay. Alterations made in proofs, other than the correction of printer's errors, are charged to the author.

\section{Reprints}

Order forms and a price list are sent with the proofs. Orders submitted after the issue is printed are subject to considerably higher prices.

\section{KARGER}

E-Mail karger@karger.com www.karger.com
(C) 2013 S. Karger AG, Basel 


\section{Chemotherapy}

ISSN Print Edition: 0009-3157

ISSN Online Edition: 1421-9794

Journal Homepage: www.karger.com/che

Publication Data: Chemotherapy is published 6 times a year. Volume 59 with 6 issues appears in 2013.

Copyright: (c) 2013 S. Karger AG, Basel (Switzerland). All rights reserved. No part of this publication may be translated into other languages, reproduced or utilized in any form or by any means, electronic or mechanical, including photocopying, recording, microcopying, or by any information storage and retrieval system, without permission in writing from the publisher or, in the case of photocopying, direct payment of a specified fee to the Copyright Clearance Center.

Disclaimer: The statements, opinions and data contained in this publication are solely those of the individual authors and contributors and not of the publisher and the editor(s). The appearance of advertisements in the journal is not a warranty, endorsement, or approval of the products or services advertised or of their effectiveness, quality or safety. The publisher and the editor(s) disclaim responsibility for any injury to persons or property resulting from any ideas, methods, instructions or products referred to in the content or advertisements.
Subscription Rates: Subscriptions run for a full calendar year. Prices are given per year. Personal subscription:

Print or Online

CHF 1164.-

EUR 939.-

USD 1153.00

Print+Online combined CHF 1212.-

EUR 978.-

USD 1201.00

postage and handling (added to print and print+online)

CHF 43.20 Europe, CHF 62.40 Overseas

EUR 33.60

USD 57.60

Institutional subscription

Print or Online

Print+Online combined

CHF 2328.

EUR 1877.-

CHF 2561.-

postage and handling (added to print and print+online)

CHF 54.- Europe, CHF 78.- Overseas

EUR 42.-

USD 72.00

Airmail surcharge: CHF 52.50 / USD 49.50
Back Volumes and Single Issues: Information on availability and prices of single print issues and print or electronic back volumes can be obtained from Customer Service atservice@karger.com.

Bibliographic Indices: This journal is regularly listed in bibliographic services, including Current Contents ${ }^{\circledR}$ and PubMed/MEDLINE.

Photocopying: This journal has been registered with the Copyright Clearance Center (CCC), as indicated by the code appearing on the first page of each article. For readers in the US, this code signals consent for copying of articles for personal or internal use, or for the personal or internal use of specific clients, provided that the stated fee is paid per copy directly to

Copyright Clearance Center Inc.

222 Rosewood Drive

Danvers, MA 01923 (USA)

A copy of the first page of the article must accompany payment. Consent does not extend to copying for general distribution, for promotion, for creating new works, or for resale. In these cases, specific written permission must be obtained from the copyright owner,

S. Karger AG, P.O. Box

CH-4009 Basel (Switzerland).

\section{Subscription Orders:}

Orders can be placed at agencies,

bookstores, directly with the Publisher

\section{S. Karger AG}

Medical and Scientific Publishers

Allschwilerstrasse 10

CH-4009 Basel

Switzerland

t: +41613061111

f: +41613061234

e: karger@karger.com

w: www.karger.com

(for courier services only:

Allschwilerstrasse 10

CH-4055 Basel) or further Karger offices

or representatives:

Germany

S. Karger GmbH

Postfach

79095 Freiburg

Deutschland

(Hausadresse: Wilhelmstrasse 20A

79098 Freiburg)

t: +49761452070

f: $\quad+497614520714$

e: information@karger.de

w: www.karger.de

Japan

Karger Japan, Inc

Shiba Daimon Asahi Bldg. 2F

1-2-23 Shiba Daimon

Minato-ku

Tokyo 105-0012

Japan

t: +81364356242

f: +81364356244

e: publisher@karger.jp

w: www.karger.jp
USA

S. Karger Publishers, Inc.

26 West Avon Road

P.O. Box 529

Unionville, CT 06085

USA

Toll free: +18008285479

$\mathrm{t}: \quad+18606757834$

f. +18606757302

e: karger@snet.net

France

Librairie Médi-Sciences Sar

36, bd de Latour-Maubourg

75007 Paris

France

t: $+33(0) 145514258$

f: $+33(0) 145560780$

f: librairie@medi-sciences.fr

w: www.medi-sciences.fr
South East Asia, China and Taiwan Karger Regional Office (Malaysia) CEO Suite Kuala Lumpur Quill 7, 27th Floor

Jalan Stesen Sentral 5

KL Sentral

Kuala Lumpur 50470

Malaysia

t: +60327766803

t: $\quad+60327766803$

e: service@karger.cn; r.chew@karger.cn

\section{Karger China}

10th Floor, Twin Towers (East)

B12 Jianguomenwai Avenue

Beijing 100022

China

$\mathrm{t}: \quad+861051235033$

f: +861051235122

e: service@karger.cn; r.chew@karger.cn

w: www.karger.cn

India, Bangladesh, Sri Lanka

Medscience India

Plot No. 17, Yusuf Sarai Market

B.L. Glass Building, 2nd Floor

Sri Aurobindo Marg

New Delhi 110016

India

t: +911146029633

f: +911146029634

c: +919891052128

e: medsci.india@gmail.com

Change of Address:

Both old and new address should be sent

to the subscription source.

\section{KARGER}

E-Mail karger@karger.com www.karger.com
(C) 2013 S. Karger AG, Basel

The Journal Home Page is available at:

www.karger.com/che 


\section{New!}

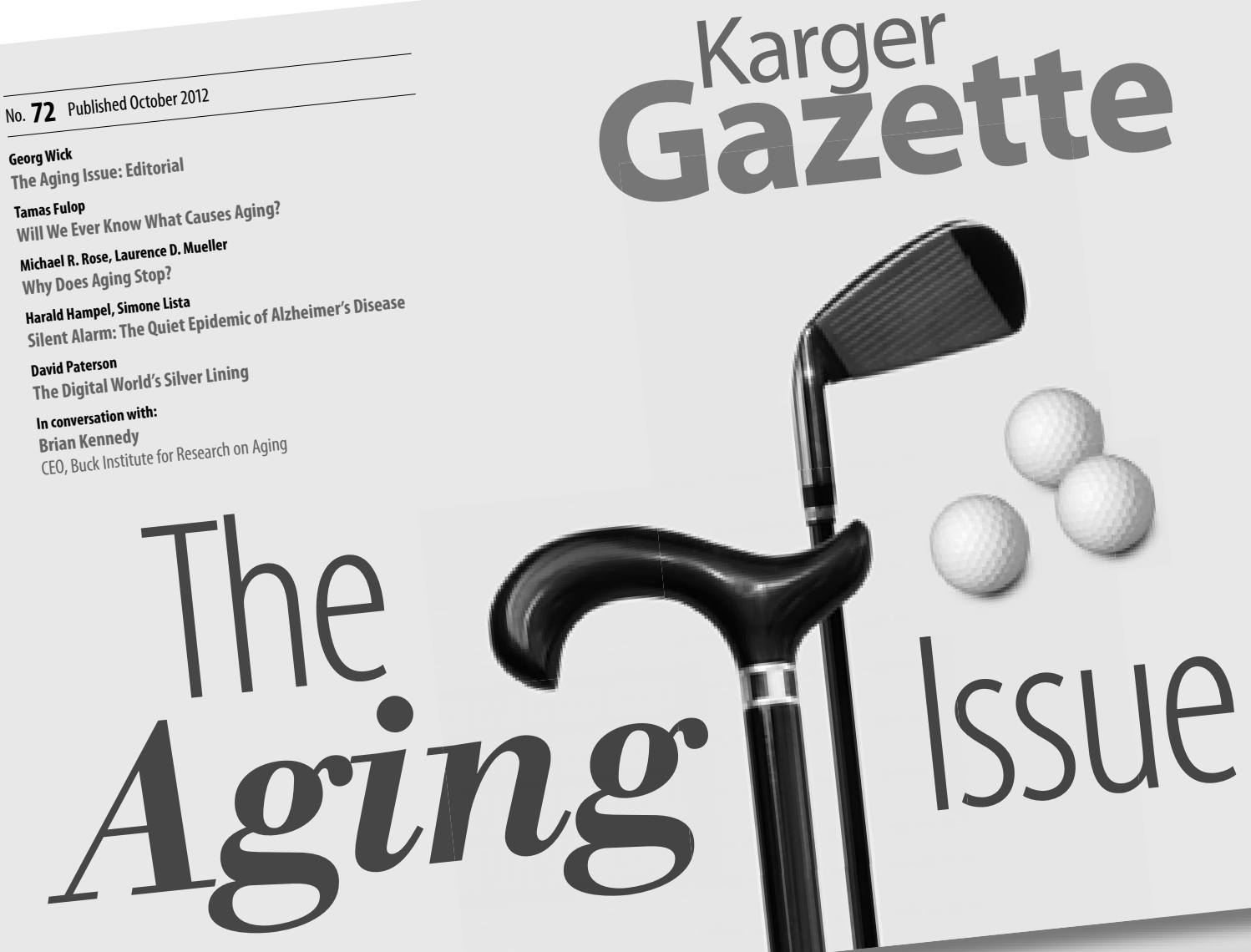

\section{Not just for specialists...}

For over 40 years the Karger Gazette has been distributed to a growing audience worldwide. Published once a year in newspaper format, it highlights advances in biomedicine and clinical practice, introduces personalities, portrays research institutes and chronicles milestones in the history of Karger Publishers in a lively and readable style. With invited contributions by experts from all over the world, each issue is devoted to a special topic of current interest. 


\section{Contents}

See the journal website for contents

KARGER Basel $\bullet$ Freiburg $\cdot$ Paris $\bullet$ London $\bullet$ New York $\cdot$ New Delhi $•$ Bangkok Beijing $\cdot$ Tokyo $\cdot$ Kuala Lumpur $\cdot$ Singapore $\bullet$ Sydney 


\begin{tabular}{|l}
\hline $\begin{array}{l}\text { Edited by the } \\
\text { International Association } \\
\text { for Biologicals }\end{array}$ \\
$\begin{array}{l}\text { The International Association for Biologicals organizes international meetings which con- } \\
\text { front the numerous practical problems involved in standardization and bring together re- } \\
\text { searchers, manufacturers, public health authorities and government officials. Books in this } \\
\text { series, which record these meetings, are respected as definitive references to current work } \\
\text { on international biological standards, biological reference preparations and biological refer- } \\
\text { ence reagents. }\end{array}$
\end{tabular}

Developments in Biologicals ISSN 1424-6074

Listed in bibliographic services, including Current Contents

Index Medicus/MEDLINE,

Reference Update,

Biological Abstracts

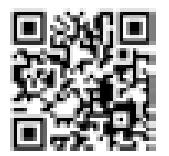

Read it online: www.karger.com/debis

Vol. 134: Potency Testing of
Veterinary Vaccines for
Animals: The Way From in Vivo
to in Vitro
International Scientific Workshop,
Langen, December 2010: Proceedings
Editor: Jungbäck, C. (Langen)
X+164 p., 36 fig., 10 tab., soft cover,
2012
CHF 105.- - EUR 88.- / USD 124.00
ISBN 978-3-8055-9892-7

ISBN 978-3-8055-9892-7

\section{Vol. 133: Viral Clearance Symposium 2009}

International Symposium, Indianapolis, Ind., March 2009: Proceedings

Editors: Miesegaes, G.; Bailey, M Willkommen, H.; Chen, Q.; Roush, D.; Blümel, J.; Brorson, K.

XII + 104 p., 36 fig., 38 tab., soft cover, 2010

CHF 105. - / EUR 88.- / USD 124.00 ISBN 978-3-8055-9682-4

\section{Vol. 132: Animal Genomics for Animal Health \\ International Symposium, Paris, October 2007: Proceedings \\ Editors: Pinard, M.-H. (Jouy-en-Josass, \\ Gay, C. (Beltsville); Pastoret, P.-P. \\ (Brussels); Dodet, B. (Lyon) \\ $X V I+440$ p., 72 fig., 72 tab., soft cover, \\ 2008 \\ CHF 410.- / EUR 342.- / USD 482.00 \\ ISBN 978-3-8055-8619-1}

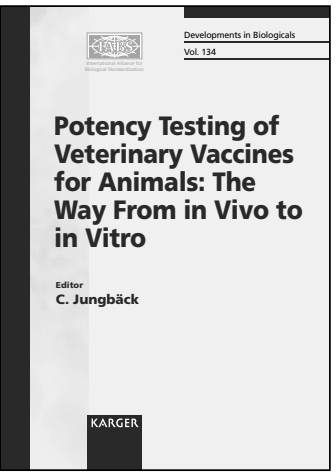

Vol. 131: Towards the

Elimination of Rabies in

Eurasia

Joint OIE/WHO/EU International

Conference, Paris, May 2007:

Proceedings

Editors: Dodet, B. (Lyon); Fooks, A.R.

Weybridge); Müller, T.

Wusterhausen/Dosse); Tordo, N.

(Paris)

XIV + 594 p., 135 fig., 75 tab.

soft cover, 2008

CHF 545 - / EUR 454 - / USD 641.00

ISBN 978-3-8055-8550-7

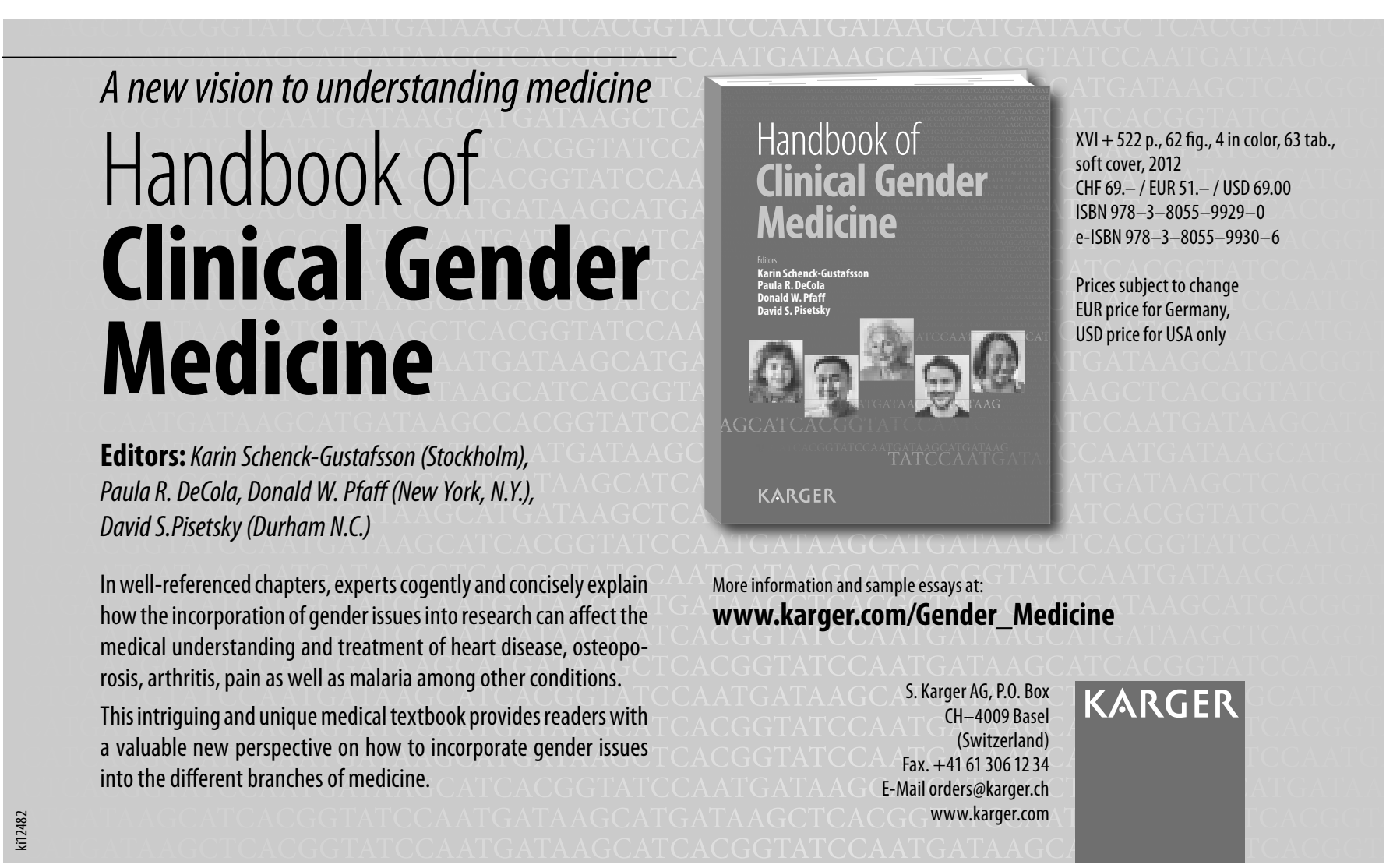




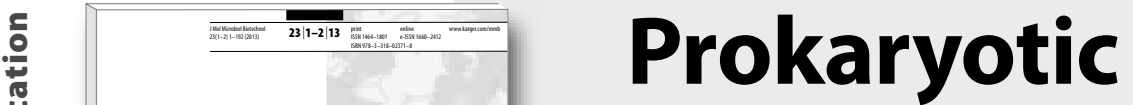 \\ Journal of \\ Molecular Microbiology and Biotechnology \\ Membrane-Bound Organelles
}

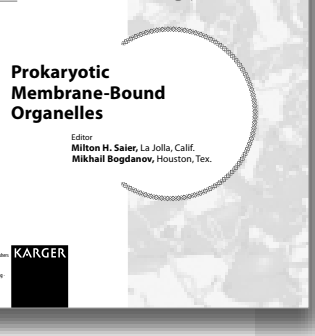

\author{
Editors \\ Milton H. Saier \\ Mikhail Bogdanov
}

Prokaryotic Membrane-Bound Organelles Editors: Saier, M.H. (La Jolla, Calif.)

Bogdanov, M. (Houston, Tex.)

192 p., 54 fig., 7 in color, 4 tab., 2013

CHF 52 - / EUR 43. - / USD 61.00 (soft cover)

CHF 62.- / EUR 52.- / USD 73.00 (online)

Online version for institutional purchase

Prices subject to change

EUR price for Germany, USD price for USA only

ISBN 978-3-318-02371-8 (soft cover)

e-ISBN 978-3-318-02372-5

Special Topic Issue

Journal of Molecular Microbiology and

Biotechnology

Vol. 23, No. 1-2 (2013)

Included in subscription

Listed in MEDLINE/PubMed

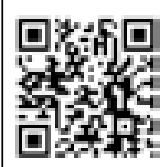

Dear Librarian

have reviewed this publication and would like to recommend it for our library.

Recommended by:

Department:

Date:

Signature:

Orders may be placed with any bookshop, subscription agency, directly with the publisher or through a Karger distributor.
The traditional view of biology divides living organisms into two major groups, the eukaryotes and the prokaryotes, the former having membrane-bound organelles, the latter lacking them. However, recent research has revealed that this view is blatantly in error. A surprising diversity of organelles occurs in bacteria. Even the prokaryotic workhorse, Escherichia coli, can produce intracellular membrane structures and bleb off extracellular vesicles. Photosynthetic bacteria have chromatophores which house the photosynthetic apparatus of the cell, while magnetotactic bacteria have magnetosomes that contain strings of membrane-enclosed iron crystals for sensing the Earth's magnetic field. Planctomycetes species may contain double membrane-surrounded nuclei as well as organelles called ammoxosomes for the oxidation of ammonia. Acidocalcisomes, once thought to be unique to eukaryotes, have also been identified in bacteria. Extracellular bacterial vesicles serve functions including communication and protection. The articles presented in this JMMB written symposium bring the reader up to date on research concerning these structures and functions.

\section{Contents}

\section{Introduction}

- Membranous Organelles in Bacteria: Saier Jr., M.H.;

Bogdanov, M.V.

Intracellular Membranes in Escherichia coli

- Membrane Invaginations in Bacteria and Mitochondria:

Common Features and Evolutionary Scenarios: Arechaga, I. - Subcellular Localization and Logistics of Integral

Membrane Protein Biogenesis in Escherichia coli:

Bogdanov, M.; Aboulwafa, M.; Saier Jr., M.H.
Chromatophores (Intracytoplasmic Membranes) in Photosynthetic Bacteria

- The Intracytoplasmic Membranes of Purple Bacteria Assembly of Energy-Transducing Complexes: Drews, G.

- Structural and Functional Proteomics of Intracytoplasmic Membrane Assembly in Rhodobacter sphaeroides: Woronowicz, K.; Harrold, J.W.; Kay, J.M.; Niederman, R.A.

Magnetosomes in Magneto-Tactic Bacteria - The Bacterial Magnetosome: A Unique Prokaryotic Organelle: Lower, B.H.; Bazylinski, D.A.

- Magnetosomes: How do They Stay in Shape?: Murat, D.

\section{Unique Organelles in Planctomycetes}

- Nested Bacterial Boxes: Nuclear and Other Intracellular Compartments in Planctomycetes: Fuerst, J.A.;

Sagulenko, E.

- The Anammoxosome Organelle Is Crucial for the Energy Metabolism of Anaerobic Ammonium Oxidizing Bacteria: van Teeseling, M.C.F.; Neumann, S.; van Niftrik, L.

Outer Membrane Vesicles

- Bacterial Outer Membrane Vesicles in Trafficking, Communication and the Host-Pathogen Interaction: Schertzer, J.W.; Whiteley, M.

- Functional Advantages Conferred by Extracellular Prokaryotic Membrane Vesicles: Manning, A.J.; Kuehn, M.J.

-The Role of Membrane Vesicles in Secretion of Lysobacter sp. Bacteriolytic Enzymes: Vasilyeva, N.V.; Tsfasman, I.M.; Kudryakova, I.V.; Suzina, N.E.; Shishkova, N.A.; Kulaev, I.S. Stepnaya, O.A.

\section{Acidocalcisomes and Organellar Evolution}

- The Coevolutionary Roots of Biochemistry and Cellular

Organization Challenge the RNA World Paradigm: Caetano-Anollés, G.; Seufferheld, M.J.

- Phylogenomics Supports a Cellularly Structured

Urancestor: Seufferheld, M.J.; Caetano-Anollés, G.

Author Index/Subject Index

\section{The easiest way to order: www.karger.com/mmb}

Karger - Medical and Scientific Publishers

CH-4009 Basel, Switzerland

orders@karger.com, f: +41 613061234

www.karger.com 


\section{The search for innovative and effective drugs begins here}

\section{Pharmacology}

\section{Pharmacology}

Editors
J. Donnerer, Graz
M.L. Billingsley,
Hershey, Pa.
K. Takeuchi, Kyoto

More information at

\section{www.karger.com/pha}

- Pay-per-View and Subscriber Access to Full Text

- Full Table of Contents

- Full Editorial Board

- Free Abstracts and Selected Articles

- Online Sample Issue

- Submission/Guidelines for Authors

- Subscription Details

- Free Alert Service

- Online Library Recommendation

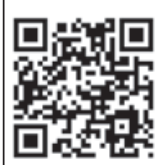

\section{Pharmacology}

2013: Volumes 91, 92

6 issues per volume

Language: English

ISSN 0031-7012 (print)

ISSN 1423-0313 (online)

\section{Selected contributions}

- A Critical Role for the Inducible Proteasomal Subunits LMP7 and MECL1 in

Cytokine Production by Activated Murine Splenocytes: Rockwell, C.E.

(East Lansing, Mich.); Monaco, J.J. (Cincinnati, Ohio); Qureshi, N. (Kansas City, Mo.)

- Anti-Inflammatory Gallic Acid and Wedelolactone Are G Protein-Coupled

Receptor-35 Agonists: Deng, H.; Fang, Y. (Corning, N.Y.)

- Absolute Oral Bioavailability of Almorexant, a Dual Orexin Receptor Antagonist, in Healthy Human Subjects: Hoch, M.; Hoever, P.; Zisowsky, J. (Allschwil); Priestley, A.

(Cambridge); Fleet, D. (Salisbury); Dingemanse, J. (Allschwil)

- Differential Treatment Regimen-Related Effects of HU210 on CB1 and D2-Like Receptor Functionality in the Rat Basal Ganglia: Nguyen, V.H.; Wang, H.

(Lucas Heights, N.S.W.); Verdurand, M. (Lucas Heights, N.S.W./Sydney, N.S.W.); Zavitsanou, K. (Lucas Heights, N.S.W.)

- Atorvastatin May Delay Cardiac Aging by Upregulating Peroxisome Proliferator-

Activated Receptors in Rats: Han, L.; Li, M.; Liu, Y.; Han, C.; Ye, P. (Beijing)

- Peripheral Control of Inflammatory but Not Neuropathic Pain by Endogenous

Cholinergic System: Motta, P.G.; Perez, A.C.; Alves, D.P.; Duarte, I.D.G. (Belo Horizonte)

- Contribution of the Amiloride-Sensitive Component and the $\mathrm{Na}^{+} / \mathrm{H}^{+}$Exchanger to

Renal Responsiveness to Vasoconstrictors: Vargas, P. (Granada); Wangensteen, R.

(Jaén); Rodríguez-Gómez, I.; Perez-Abud, R.; Osuna, A. (Granada); Quesada, A. (Jaén);

Vargas, F. (Granada)

- Beta-Arrestin2 as a Competitor for GRK2 Interaction with the GLP-1 Receptor

upon Receptor Activation: Jorgensen, R.; Norklit Roed, S.; Heding, A. (Måløv);

Elling, C.E. (Horsholm)
Pharmacology is an international forum to present and discuss current perspectives in drug research. The journal communicates research in basic and clinical pharmacology and related fields. It covers biochemical pharmacology, molecular pharmacology, immunopharmacology, drug metabolism, pharmacogenetics, analytical toxicology, neuropsychopharmacology, pharmacokinetics and clinical pharmacology. In addition to original papers and short communications of investigative findings and pharmacological profiles, the journal contains reviews, comments and perspective notes; research communications of novel therapeutic agents are encouraged. 


\section{Chemotherapy}

Microbiology

57 Acinetobacter baumannii Infections in a Tertiary Care Hospital in Mexico over the Past 13 Years

Morfín-Otero, R. (Guadalajara); Alcántar-Curiel, M.D.; Rocha, M.J.; Alpuche-Aranda, C.M.; Santos-Preciado, J.I.; Gayosso-Vázquez, C. (Mexico City); Araiza-Navarro, J.R.; Flores-Vaca, M.; Esparza-Ahumada, S.; González-Díaz, E.; Pérez-Gómez, H.R.; Rodríguez-Noriega, E. (Guadalajara)

Experimental Chemotherapy

14 Methyl Sulfone Manifests Anticancer Activity in a Metastatic Murine Breast Cancer Cell Line and in Human Breast Cancer Tissue - Part I: Murine 4T1 (66cl-4) Cell Line

Caron, J.M.; Bannon, M.; Rosshirt, L.; O’Donovan, L. (Farmington, Conn.)

24 Methyl Sulfone Manifests Anticancer Activity in a Metastatic Murine Breast Cancer Cell Line and in Human Breast Cancer Tissue - Part 2: Human Breast Cancer Tissue

Caron, J.M.; Monteagudo, L.; Sanders, M.; Bannon, M.; Deckers, P.J. (Farmington, Conn.)

51 Effects of Combined Treatment with Ambroxol and Ciprofloxacin on Catheter-Associated Pseudomonas aeruginosa Biofilms in a Rat Model Lu, Q.; Yu, J.; Bao, L.; Ran, T.; Zhong, H. (Chongqing)

1 Cisplatin plus Capecitabine as First-Line Chemotherapy for Recurrent or Metastatic Head and Neck Squamous Cell Cancer: Experience Outside of a Trial Setting McPartlin, A.J.; Mais, K.; Barker, C.; Swindell, R. (Manchester); Mitchell, K. (Preston); Sykes, A.; Lee, L.; Yap, B.; Slevin, N.J. (Manchester)
8 A Phase I Trial of Sunitinib and Rapamycin in Patients with Advanced Non-Small Cell Lung Cancer

Waqar, S.N. (St. Louis, Mo.); Gopalan, P.K. (Gainesville, Fla.); Williams, K. (St. Louis, Mo.); Devarakonda, S. (Chesterfield, Mo.); Govindan, R. (St. Louis, Mo.)

35 Feasibility Study of Adjuvant Chemotherapy of S-1 and Carboplatin for Completely Resected Non-Small Cell Lung Cancer

Komazaki, Y.; Sakashita, H.; Furuiye, M.; Fujie, T.; Tamaoka, M.; Sumi, Y.; Miyazaki, Y.; Kojima, K. (Tokyo); Jin, Y. (Kanagawa); Inase, N. (Tokyo)

42 Management of Elderly Patients with Advanced Non-Small Cell Lung Cancer: A Single-Center Experience Früh, M. (St. Gallen); Besrour, H. ( Schaffhausen); Gillessen, S.; Joerger, M.; Hitz, F.; Savidan, A.; Cerny, T.; Ess, S. (St. Gallen)

66 Hepatic Arterial Infusion with Irinotecan in Patients with Liver Metastases of Colorectal Cancer: Results of an Extended Phase I Study

Eichler, K.; Dufas, T.; Hammerstingl, R.; Gruber-Rouh, T.; Vogl, T.J.; Zangos, S. (Frankfurt am Main)

74 Successful Everolimus Treatment in a Patient with Advanced Pancreatic Neuroendocrine Tumor Who Developed Everolimus-Induced Interstitial Lung Disease on Two Occasions: A Case Report

Nakayama, Y.; Ikeda, M.; Kojima, M.; Goto, K.; Hara, M.; Okuyama, H.; Takahashi, H.; Ohno, I.; Shimizu, S.; Mitsunaga, S. (Kashiwa); Okusaka, T. (Tokyo)

65 Erratum 